\title{
Tontonan anak di Televisi: Paradoks dan Kontestasi Nilai Tontonan Anak di Media Televisi Nasional
}

\author{
Nur Hamzah ${ }^{\circledR}$, Elfan Fanhas Fatwa Khomaeny2, Maulidya Ulfa ${ }^{3}$ \\ Pendidikan Islam Anak Usia Dini, Institut Agama Islam Negeri Pontianak(1) \\ Pendidikan Guru Pendidikan Anak Usia Dini, Universitas Muhammadiyah Tasikmalaya(2) \\ Pendidikan Islam Anak Usia Dini, Institut Agama Islam Negeri Syekh Nurjati Cirebon(3) \\ DOI: $10.31004 /$ obsesi.v5i2.713
}

\begin{abstract}
Abstrak
Durasi dan intensitas menonton anak yang melebihi 4 jam dalam sehari akan membuat mereka adiksi sekaligus rentan terpapar bahaya konten negatif. Penelitian ini bertujuan untuk mengetahui ragam acara anak yang tayang di media televisi nasional, mengeksplor nilai positif dan menggambarkan nilai negatif dalam program acara anak. Menggunakan pendekatan kualitatif deskriptif dengan objek penelitian pada beberapa acara anak di media televisi nasional (Trans7, MNCTV dan TVRI). Teknik pengumpulan data berupa observasi dan dokumentasi. Untuk memeriksa keabsahan data, digunakan teknik trianggulasi dan perpanjangan waktu penelitian. Selanjutnya penelitian ini menyimpulkan bahwa ragam acara anak di televisi meliputi animasi anak dan edutainment. Kemudian terdapat nilai positif dalam tontonan anak yaitu nilai moral-spiritual, nilai sosial dan nilai budaya. Namun begitu, terdapat juga nilai negatif yakni hedonisme dan konsumerisme, nilai perilaku anti sosial serta nilai kekerasan. Secara umum penelitian menyimpulkan bahwa program anak pada televisi sebagian masih belum ramah anak.
\end{abstract}

Kata Kunci: tontonan, anak usia dini, televisi

\begin{abstract}
The duration and intensity of a child's watch exceeding 4 hours a day will make them an addiction at once vulnerable to the danger of negative content. This research aims to find out: a variety of children's events that aired on national television media, exploring positive values and describing negative values in children's events program. A qualitative approach of deskribtif is a preferred research method, with research objects on several child events in the national television media (TRANS7, MNCTV and TVRI). The data collection techniques used are observations and documentation. To examine the validity of the data, used trianggulation techniques and overtime research time. Furthermore the study concluded that: the variety of children's shows on television includes animated children and Edutainment. Then there is a positive value in the child's spectacle of moral-spiritual value, social value and cultural value. However, there are also negative values of hedonism and consumerism, the value of antisocial behaviour and the value of violence. In general, the study concluded that the children's program on television is partly still not child friendly.
\end{abstract}

Keywords: spectacle; early childhood; television

Copyright (c) 2021 Nur Hamzah, Elfan Vanhas Khomeiny, Maulidya Ulfa

$\triangle$ Corresponding author :

Email Address : hamzahptk@gmail.com (Pontianak, Indonesia)

Received 13 August 2020, Accepted 5 December 2020, Published 3 February 2021 


\section{PENDAHULUAN}

Saat ini kita berada dalam era globalisasi informasi. Globalisasi informasi adalah era dimana infromasi bersifat meluas baik sumber asalnya maupun sifat penyebarannya. Informasi bisa datang dan diproduksi dari subjek mana saja serta tertransmisi kepada siapa saja tanpa sekat waktu dan lokasi (Nurhadi, 2006). Globalisasi informasi juga menandai bahwa informasi selalu terbuka dan mengurai sekat atau batas primordial, sosial, geografis termasuk usia. Dalam bahasa yang berbeda Thomson mengatakan, berdasarkan perentangan ruangwaktu, penyebaran media teknik memisahkan interaksi sosial dari lokal fisiknya, sehingga seseorang dapat melakukan interaksi dengan orang lain sekalipun mereka tidak berada dalam setting ruang dan waktu yang sama (Thompson, 2015). Dahulu informasi bersifat tertutup dan hanya dapat diakses oleh kelompok yang dikehendaki. Saat sekarang, informasi datang tanpa sensor, bahkan bagi seorang anak usia dini sekalipun dapat mengkonsumsinya.

Dengan perkembangan teknologi informasi terbarukan, kita dihadapkan pada banyak pilihan jenis teknologi informasi, seperti komputer, gadget atau smart phone, TV kabel, internet dan masih banyak lagi (Hamzah, 2015a). Wal hasil, kita mengalami ketergantungan dengan produk teknologi informasi dan komunikasi tersebut. Sebuah data yang mencengangkan bahwa pada tahun 2015, menurut data Asosiasi Penyelanggara Jasa Internet Indonesia (APJII) pertumbuhan internet di Indonesia meningkat 34,9\% atau 82 juta dengan peringkat ke-8 dunia (Astuti et al., 2016) kemudian pada tahun 2019, Indonesia mejadi negara ke-6 terbesar sebagai penduduk dunia yang menggunakan internet degan survey penetrasi pengguna internet berjumlah $73,7 \%$ nail $64,8 \%$ dari tahun 2018. Data Badan Pusat Statistik (BPS) populasi Indonesia tahun 2019 berjumlah 266.911 .900 jiwa sehingga diperkirakan pengguna internet 196,7 juta pengguna.(Ramli, 2020)

Untuk kasus Indonesia, selain ditandai dengan perkembangan teknologi internet, perkembangan informasi dan komunikasi juga dapat dilihat dengan hadirnya televisi swasta. Pada tahun 1962 negara ini hanya memiliki 1 stasiun televisi yakni TVRI sebagai media hiburan dan informasi sehari-hari (Permana et al., 2019). Sejak tahun 90-an muncul stasiun televisi swasta yakni RCTI dan TPI, dan beruntun berikutnya lahir SCTV, MNCTV, Global TV, TransTV, Trans7, TVOne, Kompas TV, Metro TV, I News TV, Net TV, Jak TV dan masih banyak lagi. Kehadiran televisi nasional ini belum ditambah dengan televisi lokal, dimana pada masing-masing daerah memilikinya. Hal ini juga ditambah dengan stasiun televisi kabel berbayar (KPI, 2019).

Pada ranah positif, kehadiran banyak stasiun TV menghadirkan keuntungan bagi pemirsanya (Desti, 2005). Diantaranya adalah ragam pilihan acara. Penonton dapat memilih banyak alternatif ragam acara mulai dari musik, olah raga, berita, sinetron, film, kuliner dan lain sebagainya. Pemirsa begitu dimanjakan dengan varian acaranya. Namun tak dapat dihindari, kehadiran televisi swasta yang banyak ini menghadirkan kompetisi ketat antar stasiun TV. Sebagai konsekuensi para pemegang bisnis pertelevisian harus memutar otak dan menyusun strategi matang untuk merebut penonton dimana iklan sangat tergantung kepada hal ini. Komptetisi yang menjurus tidak sehat, cendrung melahirkan tontonan minim kualitas.

Tontonan yang tidak berkualitas atau kecil manfaat sejatinya bagi orang dewasa bukan menjadi masalah besar sebab mereka memiliki struktur dan mekanisme filter internal, tetapi tidak demikian dengan anak, oleh sebab itu keluarga memiliki peranan penting dalam mendampingi kegiatan menonton anak (Adelman \& Adelman, 2018). Radesky dan Domoff menyebutkan bahwa struktur kognitif, moral dan psikologis yang dimiliki oleh anak belum matang, ia masih dalam tahapan perkembangan, sehingga belum mampu memilah tayangan televisi yang edukatif dan pas dengan perkembangannya (Radesky \& Domoff, 2019). Anak juga belum dapat memilih dan menganalisis tayangan yang berdampak negatif dan positif. Pada ranah ini anak rentan terpapar nilai yang berasal dari apa yang ditontonnya. Menurut Thomson, bahwa perkembangan media komunikasi massa berdampak pada pengaturan kehidupan sosial sehari-hari, tidak terkecuali pada anak (Thompson, 2015). Kecendrungan 
masyarakat modern yang serba instan dan cepat, terkadang melupakan nilai yang terkandung dalam produk modernisasi tersebut termasuk sebuah tontonan (Fansuri et al., 2011).

Dapat dipahami, tontonan mengandung nilai positif juga negatif. Nilai secara terminologis menurut Driyarkara sebagaimana yang dikutip oleh Subur, adalah hakikat atau sublimasi makna yang karenanya menyebabkan ia dicari. Lain lagi menurut Bertens, nilai adalah sesuatu yang disukai, diinginkan, dikehendaki dan disenangi oleh individu (Subur, 1970). Singkatnya, nilai adalah sesuatu yang baik. Pada wilayah ini maka akan terjadi proses kontestasi nilai, baik antar nilai yang ada dalam tontonan tersebut maupun antara nilai dalam tontonan dengan nilai eksternal yang diproduksi oleh institusi keluarga, lembaga pendidikan, masyarakat, agama dan institusi lainnya.

Lalu bagaimana dengan acara anak? Beberapa stasiun televisi memang membuat program acara khusus untuk anak. Di global TV terdapat film kartun spongebob squaer pant, Naruto, Dragon Ball dan lain-lain, di MNCTV ada Shaun the ship, Upin dan Ipin, Sopo Jarwo dan Pada Zaman Dahulu. Di Trans 7 punya acara Si Bolang, Dunia Binatang dan Laptop Si Unyil. dan masih banyak lagi, serta di TV lain juga demikian.

Secara ideal, kita menghendaki program atau tontonan yang ramah anak. Program televisi atau tontonan ramah anak adalah keseluruhan program mulai dari materi tontonan hingga iklannya yang berisi tentang dunia anak yang dapat membantu 5 aspek pengembangan mereka yaitu moral-spiritual, kognitif, bahasa, sosial-emosional dan fisik (Astarini et al., 2018; Desti, 2005; Fadlurrohim et al., 2020). Penelitian yang penulis lakukan ini memberikan gambaran tentang nilai apa saja yang ditransmisikan melalui sebuah program tontonan, dengan demikian akan terpetakan seberapa positif dan negatif tontonan anak di televisi nasional kita. Tujuan dilakukannya penelitian ini adalah untuk menemukenali tentang ragam acara anak yang tayang pada TV Nasional sekaligus mengeksplor nilai positif (moralspiritual, sosial dan budaya) juga nilai negatif yang ada dalam program tersebut.

Ada banyak penelitian tentang pengaruh televisi, namun baru sedikit yang memfokuskan pada tayangan khusus anak. Tahun 2013 penulis juga pernah melalukan penelitian serupa yakni: program acara anak di Trans 7: Si Bolang dan Laptop Si Unyil. Kesimpulan umumnya bahwa dua acara ini memiliki banyak nilai positif baik nilai pendidikan maupun nilai kultural ke-Indonesiaan. Walaupun demikian, terdapat catatan kecil, bahwa iklan yang tayang pada dua acara ini beberapa diantaranya tidak baik untuk ditonton karena tidak sesuai dengan karakteristik anak.

Berikutnya sebuah penilitian yang dilakukan oleh Efendi et al. (2017), tentang analisis pengaruh penggunaan media baru terhadap pola interaksi sosial anak di kabupaten Sukoharjo. Riset ini menyimpulkan bahwa tontonan pada media baru (new media) memberi pengaruh besar pada pola interaksi sosial anak. Subjek pada anak kelompok usia 8-12 tahun. Secara lebih khusus dinyatakan bahwa penggunaan media baru di kalangan anak usia 8-12 tahun di Sukoharjo dalam kategori sedang dan interaksi sosialnya dalam kategori tinggi. Asumsi yang menyatakan bahwa semakin tinggi penggunaan media baru (termasuk menonton) maka interaksi sosial anak akan cenderung semakin rendah dapat diterima kebenarannya dengan koefisien korelasi sebesar 0,54 pada derajat kebebasan 0,05 atau tingkat kepercayaan 95\%. Penelitian ini menggunakan metode kuantitatif.

Penelitian terhadap anak yang sering menonton acara kartun Spongebob dalam Astarini et al. (2018), dituliskan penelitian dari Angelina Lillard dan Peterson Jenifer dari University of Virginia, beberapa acara televisi anak-anak memang berakibat buruk untuk otak anak. Dampak buruk juga terdapat pada kartun yang mereka sebut dengan istilah "animated kitchen sponge" atau yang kita kenal dengan kartun Spongebob. Dampaknya adalah anak-anak tidak bisa berkonsentrasi atau fokus dengan baik setelah menonton film kartun tertentu.

\section{METODOLOGI}

Penelitian ini menggunakan pendekatan kualitatif dengan metode deskribtif (Emzir, 2016). Pendekatan kualitatif deskribtif dipilih dengan maksud agar data sebagai fakta 
ditampilkan apa adanya. Posisi peneliti hanya subjek pemapar dan untuk berikutnya dianalisis menggunakan bekal teori yang telah dirancang sebelumnya. Teknik pengumpulan data dilakukan dengan cara observasi dan dokumentasi. Data yang dikumpulkan meliputi: ragam program acara anak, asal produksi, konten materi tontonan, dan jenis iklan yang tayang. Setelah melihat dan menganalisis tayangan, barulah peneliti mengkategori nilai. Sumber data penelitian ini adalah beberapa media televisi nasional yakni: Trans7, MNCTV, TVRI dan Indosiar. Beberapa stasiun televisi dimaksud adalah stasiun televisi yang banyak menayangkan acara anak dan mewakili kelompoknya masing-masing. Trans7 mewakili Transcrop media, MNCTV mewakili MNC Group, Indosiar mewakili Emtek Group dan TVRI adalah stasiun TV milik pemerintah.

Selama melakukan observasi (menonton acara anak), peneliti membuat catatan terhadap fakta dan data yang berkaitan dengan masalah penelitian dan melengkapinya dengan refleksi peneliti terhadap hasil observasi. Penyusunan catatan lapangan ini dibuat dengan menggunakan pedoman sebagaimana yang diungkapkan oleh Spredly yaitu: (1) mengidentifikasi bahasa, yaitu bahasa yang digunakan; (2) verbatim, yaitu mencatat ucapan atau perkataan sebagaimana yang dilakukan oleh pelaku. Pemeriksaan keabsahan data dilakukan dengan trianggulasi, perpanjangan waktu penelitian dan diskusi teman sejawat (Nazir, 2003).

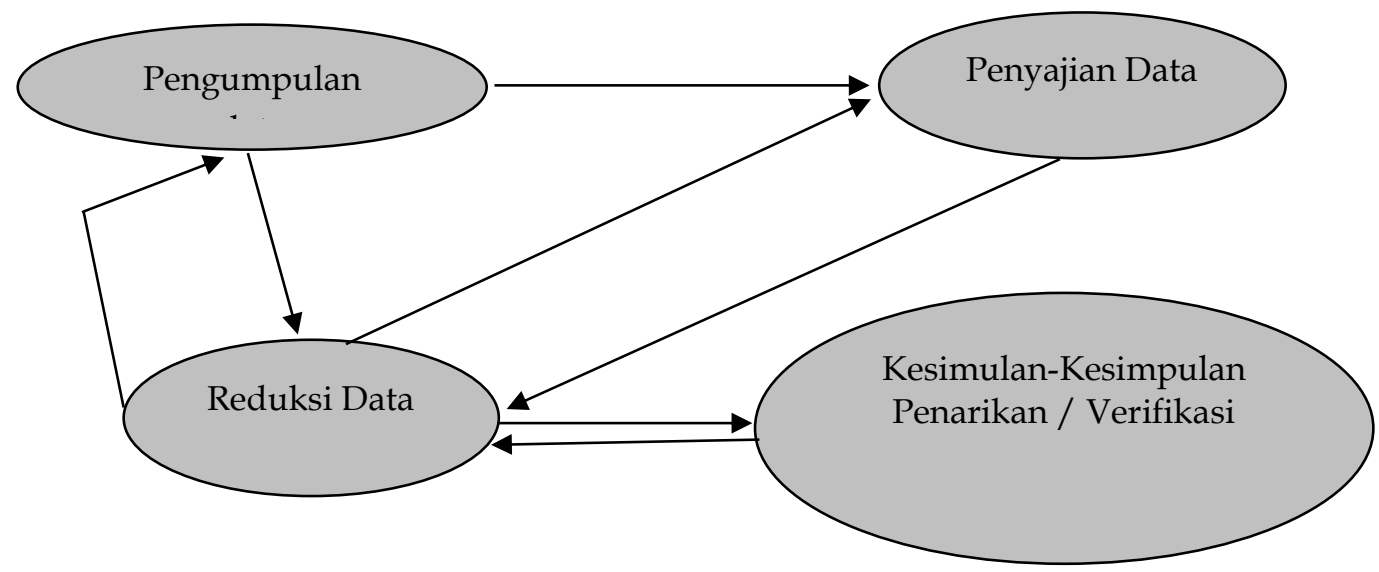

Gambar 1. Desain penelitian

\section{HASIL DAN PEMBAHASAN}

Jika melihat fakta sekarang, televisi telah menjadi sahabat aktif anak-anak di rumah. Televisi telah menjalankan fungsi ganda yakni sarana penghibur juga menjadi tutor kehidupan pengganti orang tua dan guru. Data menurut Yayasan Pengembangan Media Anak (YPMA) tahun 2010 menyebutkan bahwa anak Indonesia memiliki kebiasaan menonton TV sekitar 7-8 jam dalam sehari (Syukri et al., 2019). Kebiasaan menggunakan media baru oleh anak-anak berikutnya sangat berpengaruh terhadap pembentukkan perilaku mereka, termasuk ketika anak membangun relasi dengan orang tuanya, anggota keluarga lain, teman dan orang lain disekitarnya (Fadlurrohim et al., 2020; Ulfah, 2020). Theresa Orange dan Louise O'Flynn dalam buku The Media Diet for Kids menyebutkan hasil perilaku yang diperoleh dari praktik menonton TV antara lain perilaku anti sosial, apatis, anak mulai paham dan mengetahui seks secara samar, dewasa dini, dan terjadinya ketidakseimbangan energi. Sarah dalam penelitian juga menjelaskan ada keprihatinan internasional terkait meningkatnya penggunaan media pada anak usia dini yang dipengaruhi oleh faktor orangtua (Orange, 2005).

Jean Baudrillard mengatakan bahwa media senyatanya adalah simulacra. Simulacra adalah sebuah konsep yang ingin menunjukkan bahwa para penonton media (televisi, atau melalui gadjet) memandang apa yang terdapat dalam tontonan merupakan realitas sesungguhnya (Adegan et al., 2011). Individu dibawa pada sebuah framing kenyataan, fakta 
bukan pada apa yang terjadi secara objektif melainkan apa yang terepresentasikan pada layar media. Terjadi pemutarbalikkan epistimologi., Seharusnya media tontonan adalah rekayasa dari kejadian yang belum tentu empirik, tetapi individu menganggapnya sebagai sesuatu yang ojketif dan ia membuat narasi atasnya. Sebagai contoh remaja yang selalu menonton sinetron dengan konten pertentangan antara anak dan orang tua dalam keluarga kota, hal ini akan menyebabkan persepsi kepada remaja tersebut, bahwa orang tua dan anak selalu dalam posisi oposisi binner atau pertentangan. Individu cendrung menganggap bahwa orang tua dengan otoritasnya selalu memaksakan kehendak yang berbeda dengan kemauan anak. Pada hal senyatanya dalam kehidupan empirik, banyak orang tua dan anak dalam pola hubungan relasional positif. Demikian seterusnya.

Nilai-nilai yang ditransmisikan sebuah tayangan program diadopsi oleh anak untuk dijadikan perilaku. Dalam teori belajar sosial Albert Bandura dijelaskan bahwa anak belajar menggunakan model(LESILOLO, 2019). Model dimaksud adalah apa yang dilihat, dialami dan didengar dari orang dewasa. Anak akan melakukan hal serupa sebagaimana yang dilakukan oleh orang tua, guru dan orang dewasa lainnya. Melalui media baru, perilaku orang dewasa saat ini telah tersubsitusi dalam sebuah tontonan yang ada dalam layar kaca baik di televisi atau gadget. Jadi, anak juga akan menjadikan televisi dan totonan dalam gadget sebagai model untuk diduplikasi (Ulfah, 2019).

Televisi, sebagaimana Gerbner, dianggap sebagai pendominasi "lingkungan simbolik" kita. Sebagaimana McQual dan Windahl mencatat pula, teori kultivasi menganggap bahwa televisi tidak hanya disebut sebagai gambara atau refleksi fakta atau kejadian sehari-hari, melainkan ia adalah dunia itu sendiri (McQuail, Dennis, 1985). Gerbner mengasumsikan bahwa media massa telah menginternalisasikan sikap dan nilai tertentu. Media berkutnya memelihara dan mentransformasikan sikap dan nilai itu antar individu dalam masyarakat, lalu mengikatnya secara bersama-sama pula. Dengan istilah berbeda, media secara meyakinkan mempengaruhi penontonnya dan membuat hal tersebut adalah yang sebenarnya secara meyakinkan. Jadi, para pecandu televisi itu memiliki kecenderungan sikap dan sikap yang sama satu dengan yang lainnya. Televisi bermanfaat untuk peningkatan semua aspek perkembangan anak usia dini sehingga anak menjadi lebih komunikatif, imaginatif, dan aktif. Sedangkan dampak negatifnya berupa penurunan prestasi belajar anak yang akibat terlalu sering menonton televisi (Adegan et al., 2011). Jadi, meskipun televisi atau tontonan bukanlah satu-satunya wadah yang membentuk cara pandang dan perilaku seseorang termasuk anak, televisi merupakan salah satu media yang paling ampuh, terutama bila kontak dengan televisi dengan intensitas sangat sering dan berlangsung dalam waktu lama. Pada wilayah ini maka pendampingan orang tua secara bersama-sama menjadi penting ( $\mathrm{Na}^{\prime} \square$ imah, 2009).

\section{Ragam Acara Anak}

Dalam sebuah produksi program, stasiun TV telah menentukan siapa yang menjadi segmen sasaran. Dengan memilih segmen, stasiun TV akan lebih fokus dalam menggarap sebuah tayangan unggul yang menjadi distingsi terhadap stasiun TV lainnya. Upaya memilih segemen penonton dalam perspektif ekonimi dapat dikatakan sebagai upaya merebut jumlah penonton. Jumlah rating dan Share menjadi tujuan agar stasiun TV tetap eksist dan survive (Rubiyanto, 2018). Di Indonesia kita mengenal TV One, Metro TV, Kompas TV dan I News yang merupakan stasiun TV berita. Segmen dari kelompok ini jika menggunakan klasifikasi generasi Presnky adalah para digital imigrant atau generasi yang lahir sebelum tahun 1980an. Generasi ini lebih menyukai terutama kaum laki-laki tayangan informatif dan edukatif. Berita terkini lokal, nasional, regional, dan international dan dialog lintas perspektif adalah core programnya.

Kemudian kita mengenal RCTI, SCTV, Indosiar dan Trans TV. Tiga stasiun TV ini mengambil segmen kaum perempuan baik dari kelompok umur digital imigrant ataupun digital natives. Corak atau kecendrungan acaranya adalah variety show dan intertainment atau hiburan. Didalamnya dikemas dalam bentuk sinetron, film layar lebar, gosip artis, musik, 
edu-family show dan lain-lain. Segmen ini juga kemudian dikelompokkan semakin spesifik oleh stasiun TV. Ada yang mengambil perempuan urban seperti RCTI dan SCTV, sementara MNCTV dan Indosiar menyasar perempuan sub-urban dan rural. Berikutnya ada juga stasiun TV yang menyasar kelompok laki-laki muda yakni Trans7. Pada mata programnya banyak tentang olah raga, petualangan alam dan hoby. Pada TV ini ada acara live MotoGP, highlight liga bola nasional dan international, badminton yang merupakan olah raga populer kedua di Indonesia, jejak petualang, jalan-jalan alam liar, selebrity on vacation, on the spot yang merupakan cuplikan-ciplikan viral di dunia maya, mancing mania dan masih banyak lagi. Segemen utamanya adalah para kaum hawa millenial.

Khusus program anak, diantara sekian banyak stasiun TV hanya ada satu TV yang khusus mengambil segmen anak yaitu RTV. Hanya kelemahannya adalah, jangkauan siarnya masih sangat terbatas, lalu tidak memproduksi program sendiri dan lebih banyak pengulangan. Sementara pada stasiun TV mainstream nasional, acara anak hanya mendapat sedikit porsi jam tayang, bahkan ada yang tidak sama sekali. Fakta lain juga adalah hampir sebagian besar program anak merupakan produk impor dari Jepang, Eropa dan Malaysia. Hanya sedikit yang merupakan produksi internal corporate TV seperti Si Bolang, Laptop Si Unyil, Adit Sopo Jarwo, Keluarga Somat, Nussa dan Rara, Dunia Binatang dan masih ada beberapa. Padahal jika ditelisik, Indonesia tidak kekurangan sumber daya yang mampu membuat sebuah tayangan semisal kartun animasi atau jenis program lainnya.

\section{Nilai Spiritual}

Diantara fungsi televisi adalah sumber nilai. Oleh sebab itu penontonnya dapat belajar baik secara langsung dan sadar atau secara tidak langsung serta tidak sadar melalui sebuah tontonan. Kebanyakan yang terjadi adalah penonton menyerap nilai dari televisi secara tidak sadar, jika hal tersebut dilakukan dalam kegiatan menonton dengan durasi yang lama. Namun perlu disadari bahwa nilai yang ada pada sebuah tontonan bersifat netral. Ia memiliki nilai baik sekaligus nilai buruk. Nilai baik tersebut misalnya nilai spiritual, nilai sosial, nilai budaya, nilai moral dan lain sebagainya (Artha, 2016). Berdasarkan hasil observasi peneliti pada kartun Upin dan Ipin, Nussa dan Rara serta Adit Sopo Jarwo, maka diidentifikasi terdapat nilai spiritual dalam animasi tersebut (Nurwita, 2019; Sayekti, 2019). Nilai tersebut meliputi Pertama: nilai ketauhidan yang meliputi: keesaan Tuhan, kebesaran dan keagungan Tuhan, Tuhan sebagai Pencipta dan Tuhan yang memiliki kehendak/kuasa kepada makhluk-Nya. Hal ini dapat dilihat pada animasi kartun Ipin dan Upin episode: Esok Puasa, Nikmat, Terawih, Hari Raya, Lailatul Qadar, Riang Raya, Pengalaman Puasa, Al-kisah malam Puasa dan masih beberapa lagi. Berikutnya yang lebih kental adalah ada pada animasi Nussa dan Rara. Dikatakan kental sebab animasi ini sengaja diproduksi untuk mengisi genre agama dalam hal ini adalah Islam. Hampir semua episodenya memiliki nilai Tauhid.

\section{Nilai Ibadah}

Nilai kedua adalah Nilai Ibadah. Nilai ibadah adalah nilai mengabdi sebagai hamba kepada Pencipta. Nilai ini secara praktis mengajak penonton untuk melakukan semua perbuatan sebagai ibadah. Ibadah dapat berupa mahdhah atau ghairu mahdhah. Ibadah mahdhah merujuk pada rukun Islam atau ibadah lain yang dicontohkan Rasulullah. Sementara ibadah ghairu mahdhah menyangkut muamalah dengan niat ibadah. Pada animasi Nussa dan Rara kita dapat melihat nilai ini disajikan kepada penonton. Pada episode: Tidur sendiri gak takut, anak diajarkan beberapa hal: sebelum tidur berwudlu terlebih dahulu, membersihkan tempat tidur, membabaca Basmallah, membaca ayat Qur'an dan terakhir berdoa (Sayekti, 2019). Demikian pula pada animasi Ipin dan Upin pada episode Nikmatnya Berpuasa dan Sholat Taraweh. Kedua episode ini mengajak anak untuk belajar berpuasa sebagai pelaksanaan rukun Islam dan diikuti dengan ibadah sunnah lainnya seperti tadarus, memperbanyak sedaqah dan shalat taraweh (Nurwita, 2019). 
Sebagai temuan, bahwa nilai spiritual hampir tidak ada pada program anak yang berasal dari Eropa, Jepang dan Korea. Nilai spriritual hanya ada pada program anak yang diproduksi oleh Indonesia sendiri dan Malaysia. Nilai spiritual yang peneliti temukan pun lebih khusus pada nilai spirirtual yang bersumber dari Islam. Ini bisa saja disebabkan karena negara asal produksi yang mayoritas menganut keyakinan sebagai muslim. Dalam teori komunikasi massa hal ini mendapatkan penjelasannya bahwa nilai diproduksi oleh personal atau institusional tertentu tergantung dari latar dan interest si pembuatnya.

\section{Nilai Moral}

Sebagaimana hasil observasi pada animasi: Si Bolang, Laptop Si Unyil, Nussa Rara, Ipin dan Upin, Adit Sopo Jarwo, maka peneliti mendapati beberapa nilai moral pada program animasi tersebut. Beberapa nilai moral itu antara lain: nilai relegius, nilai jujur, disiplin, amanah, kreatif, kerja keras, bertanggung jawab dan kecintaan terhadap lingkungan. Dalam salah satu episode animasi Adit, Sopo dan Jarwo dengan judul Sunatan Massal jangan Asal, diceritakan akan dilakukan program sunnatan massal di kampung. Oleh bang Jarwo hal tersebut dimanfaatkan untuk mengambil keuntungan dengan berbohong kepada orang kampung bahwa sunnatan massal dikenakan biaya dan biaya tersebut disetorkan kepadanya sebagai koordinator. Tapi malang bagi bang Jarwo ia mendapatkan musibah dan disebabkan musibah tersebut terbongkar kebohongan dan penipuan yang ia lakukan. Nilai moral yang ingin disampaikan kepada penonton adalah larangan berbohong, menipu, memanfaatkan kesempatan untuk menarik keuntungan pribadi dan setiap perbuatan jahat akan mendapatkan balasannya. Nilai moral ini tentu saja relevan dengan nilai mana saja dalam setiap keyakinan dan berlaku dalam komunitas sosial apapun. Mempraktekkan nilai moral berarti menjunjung perintah yang Maha Kuasa sekaligus taat terhadap aturan normatif dalam komunitas sosial tertentu. Nilai moral menjadi diantara nilai paling penting ditransfer kepada anak usia dini mengingat ia akan menjadi pondasi perilaku mereka pada masa remaja, dewasa dan tua (Ananda, 2017). Banyak ragam cara dapat dilakukan orang tua untuk menanamkan nilai moral pada anak diantaranya dengan memberi tauladan, mendongeng, membacakan kisah teladan termasuk melalui tontonan.

\section{Nilai Sosial}

Bagi anak usia dini, hampir semua aspek dari manusia telah berkembang pada masa ini; aspek fisik (otak, tubuh dan gerak), psikis (kognitif, konsep, bahasa dll) dan sosial emosional (emosi, sosial, sikap, moral dll). Menurut beberapa penelitian bahkan hampir 50\% potensi yang ada pada orang dewasa telah ada pada masa anak-anak (Nurani Sujiono, 2007). Dalam konteks perkembangan sosial anak, perkembangan sosial berarti perolehan kemampuan berperilaku yang sesuai dengan tuntutan sosial. Menjadi orang yang mampu bermasyarakat memerlukan tiga proses. Ketiga proses ini terpisah dan sangat berbeda tetapi saling berkaitan, sehingga kegagalan dalam satu proses akan menurunkan kadar sosialisasi individu. Ketiga proses sosialisasi itu adalah: Belajar, berperilaku yang dapat diterima secara sosial; setiap kelompok sosial memiliki norma sosialnya sendiri-sendiri. Untuk dapat bersosialisasi selain mengetahui norma yang berlaku tersebut anak sekaligus harus menyesuaikan dan berperilaku sebagaimana norma umum tersebut. Kedua, memainkan peran sosial yang dapat diterima dan Ketiga, perkembangan sikap sosial; untuk bermasyarakat anak harus menyukai orang lain dan berbagai aktivitas sosial lainnya. Jika mereka dapat melakukan hal ini maka ia akan diterima dalam kelompok sosialnya (Artha, 2016).

Merujuk pada beberapa program anak yang diobservasi, nilai sosial yang terkandung pada program tersebut dapat diidentifikasi sebagai berikut: nilai kerjasama, kepedulian sosial, simpati dan empati, tolong menolong dan kerukunan. Dalam hampir semua program anak, peneliti mendapatkan nilai kerjasama ini, Upin dan Ipin, Keluarga Somat, Nussa dan Rara, Adit, Sopo dan Jarwo, Si Bolang dan lain-lain, termasuk animasi dari Jepang. Dalam penelitian 
berikut untuk sampel pada aspek nilai sosial, peneliti mengangkat program anak Si Bolang. Di acara Si Bolang, selalu ada main dan permainan, dalam hal ini adalah permainan lokal tradisional. Hampir semua permainan yang dimainkan oleh anak adalah permainan kelompok, Permainan kelompok menuntut kerjasama, kekompakkan, pembagian kerja dan saling bantu untuk tujuan bersama yaitu memenangkan permainan (Hamzah, 2015b).

Nilai sosial yang lain adalah kepedulian atau kepekaan sosial (Viandari \& Susilawati, 2019). Peka Sosial; Program si Bolang adalah film yang mengambil setting di daerah kampung atau desa yang ada di Indonesia. Jika diperhatikan, semua setting menampilkan potret kehidupan bersahaja, perilaku sosial masyarakat pedesaan yang penuh dengan keramahan, kepedulian dan kepolosan. Kesederhanaan juga menjadi potret masyarakat di kampung, dimulai dari pakaian, sajian menu makanan dan termasuk alat mainan yang digunakan oleh anak-anak. Oleh sebab itu, maka diantara nilai yang dapat dieksplor dari tayangan ini adalah untuk menggugah rasa peka sosial anak.

Selanjutnya adalah nilai sosial tolong menolong dan tim work. Konsep acara si Bolang memang menggunakan beberapa tokoh, yaitu si Bolang sebagai tokoh utama, dan tiga orang tokoh teman Bolang. Tiga teman Bolang adalah tokoh pendamping yang menemani Bolang baik bermain maupun melakukan suatu pekerjaan. Pada konsep ini, nilai yang disampaikan adalah si bolang dan kawan-kawan membangun kerjasama tim baik dalam permainan ataupun mengerjakan sesuatu.

\section{Nilai Budaya}

Nilai budaya merupakan seperangkat nilai yang disepakati dan terpatri dalam kelompok masyarakat, insitusi atau organisasi, atau lingkungan masyarakat, yang telah menjadi kebiasaan, kepercayaan (believe), dan simbol, dengan karakteristik tertentu yang bisa membedakannya satu dan lainnya sebagai acuan dalam prilaku dan tanggapan atas apa yang akan terjadi atau sedang terjadi. Nilai budaya dalam kontek penelitian ini adalah sikap dan perilaku dalam menghargai budaya, nilai mencintai budaya dan nilai menumbuh kembangkan budaya. Diantara nilai budaya dalam tontonan anak adalah pertama: nilai untuk menghargai warisan budaya. Dalam era globalisasi saat ini, rasanya hampir tidak ada aspek yang tidak dipengaruhi oleh budaya dan karakteristik globalisasi; pola pikir, gaya hidup, hingga mainan dan permainan anak-anak. Sudah menjadi kesadaran bersama, saat sekarang banyak mainan dan permainan tradisional hilang. Ia tergerus oleh permainan juga alat permainan produksi pabrikan. Jika melihat acara si Bolang, apa yang dimainkan oleh Bolang dan temantemannya adalah upaya dari Trans7 untuk mengenalkan kembali kepada anak-anak Indonesia akan permainan dan alat permainan yang genuine dari Indonesia. Tetapi hal lain yang sangat lebih penting adalah bahwa ini merupakan diantara ikhtiar kreatif dalam menghargai sekaligus melestarikan warisan budaya lokal asli Indonesia.

Demikian pada animasi Upin dan Ipin. Dengan latar kampung Durian Runtuh, animasi ini sangat kental menonjolkan nilai kebudayaan yang dimiliki oleh Malaysia. Didalamnya ada karakter Melayu sebagai suku mayoritas dan utama, ada karakter Tionghoa yang dimainkan oleh Meymey dan Toh Ahong, identitas India melalui karakter Jarjit dan Uncle Mutu dan manarik ada juga karakter Indonesia Jawa lewat tokoh Susanti (Nurwita, 2019).

Kedua: Mencintai budaya lokal. Selain mengenalkan akan permainan juga alat main yang berasal dari berbagai macam daerah di Indonesia, film semi documenter si Bolang juga memiliki manfaat agar anak yang menonton acara ini lebih mencintai budaya dan tradisi lokal di tengah serbuan budaya dan tradisi asing. Ketiga: Membangun dan Mempertahankan Budaya. Budaya adalah hasil olah pikir dan kreatifitas manusia. Oleh sebab itu semakin banyak budaya suatu bangsa maka hal tersebut menunjukkan tinggi tingkat berpikir dan kreatifitasnya, begitu sebaliknya. Oleh sebab itu, ikhtiar pendidikan merupakan upaya untuk mempertinggi kreatifitas berpikir untuk melahirkan budaya baru yang genuine agar tidak 
tenggelam oleh budaya luar. Si Bolang dengan materi acara yang sedemikian rupa adalah bentuk upaya lain untuk membangun budaya sendiri.

\section{Nilai-nilai Negatif}

Dalam banyak hasil riset terkini banyak anak di dunia ini lekat dengan tontonan baik televisi terutama gadget. Riset Tesa Alia misalnya menyebutkan durasi anak Indonesia menonton televisi jika dalam masa sekolah adalah sekitar 3 jam sehari dan 7.4 jam sehari pada hari libur (Alia, 2018). Peran digital parenting sangat diperlukan dalam mendidik anak di era digital seperti parental control, menjaga keseimbangan dunia digital dengan dunia nyata dan membimbing anak agar tidak kecanduan (Maisari \& Purnama, 2019).

Banyak keuntungan dalam kegiatan menonton anak jika dilakukan secara benar, tetapi dampak negatif juga jauh lebih besar akan didapat anak jika dilakukan tanpa bimbingan orang tua (Ulfah, 2020). Dalam sebuah tontonan, terkandung nilai negatif baik dari konten program atau iklan yang tayang pada acara tersebut (Hamzah, 2015a). Nilai negatif yang terdapat dalam acara anak di TV nasional Indonesia diantaranya nilai hedonisme dan konsumerisme, nilai perilaku anti sosial dan nilai kekerasan.

Nilai negatif ini teridentifikasi dalam materi tontonan, juga dalam iklan yang tayang disela-sela acara tersebut. Diantara iklan yang tayang misalnya: iklan makanan ringan, iklan susu, iklan shampo, iklan sabun, iklan telekomunikasi dan iklan obat. Diantara iklan mengandung nilai hedonisme dan konsumerisme. Sementara perilaku anti sosial yang terdapat dalam tontonan yakni perilaku: agresi, pertengkaran, mengejek dan menggertak, perilaku yang sok kuasa, egosentrisme, prasangka dan antagonisme. Perilaku anti sosial ini banyak pada jenis program anak yang berasal dari Jepang dan Korea. Atas dasar identifikasi nilai negatif tersebut, selayaknya menjadi perhatian orang tua agar aktivitas menonton menjadi produktif mengembangkan nilai positif bukan justru sebaliknya menjadi media bagi anak mengadopsi nilai negatif.

Diantara yang dapat dilakukan orang tua adalah memilihkan acara yang cocok, membuat aturan dalam menonton, membuat jadwal menonton, mendampingi anak saat menonton dan masih banyak lagi. Berdasarkan riset lain, mengembangkan nilai positif yang lain dengan menyediakan lingkungan yang alamiah dan membiasakan aktivitas fisik secara terprogram, terarah dan berkelanjutan.(Khomaeny et al., 2020)

\section{SIMPULAN}

Tidak semua stasiun televisi Indoensia memiliki program anak. Program anak yang tayang mengandung nilai positif dan negatif didalamnya. Nilai positif rata-rata terdapat pada program anak yang diproduksi dari Indonesia dan juga Malaysia, sementara nilai negatif terdapat pada banyak program anak yang berasal dari Jepang dan Korea serta iklan yang tayang pada acara anak tersebut. Terkait dengan hal tersebut, maka harus lebih banyak lagi varian dan jenis tontonan anak yang dibuat oleh orang-orang Indonesia agar kontennya sesuai dengan karakteristik anak-anak Indonesia. Sedangkan iklan yang tayang pada acara anak harus sesuai dengan kriteria tontonan positif dan karakteristik anak. Kegiatan menonton baik televisi atau media lainnya, sebaiknya anak harus didampingi oleh orang tua.

\section{UCAPAN TERIMA KASIH}

Ucapan terima kasih kami sampaikan kepada Rektor Institut Agama Islam Negeri (IAIN) Pontianak Bapak Dr. Syarif, MA dan Ketua LP2M IAIN Pontianak yang telah mendanai riset kolaboratif ini melalui DIPA IAIN Tahun 2019. Tidak lupa pula kepada rekan mahasiswa yang menjadi relawan pengumpul data, semoga menjadi amal sholeh yang dinilai Allah SWT. Reviewer dan Editor Jurnal Obsesi: Jurnal Pendidikan Anak Usia Dini, atas masukan yang diberikan sehingga artikel ini dapat dipublikasikan. 


\section{DAFTAR PUSTAKA}

Adegan, E., Di, K., Atas, K., Kultivasi, T., Fakultas, S., Sosial, I., Negeri, U., Televisi, T., Gerbner, G., \& Kultivasi, T. (2011). Efek Adegan Kekerasan Di Televisi (Kritik Atas Teori Kultivasi Gerbner) Sumarjo Fakultas Ilmu Sosial Universitas Negeri Gorontalo. 8(September), 102-114.

Adelman, A. J., \& Adelman, A. J. (2018). Parenting in the digital age. Psychoanalytic Reflections on Parenting Teens and Young Adults, October, 7-37. https:// doi.org/10.4324/9781351262767-2

Alia, T. (2018). Pendampingan Orang Tua pada Anak Usia Dini dalam Penggunaan Teknologi Digital. A Journal of Language, Literature, Culture and Education, 14(1), 65-78.

Ananda, R. (2017). Implementasi Nilai-nilai Moral dan Agama pada Anak Usia Dini. Jurnal Obsesi: Jurnal Pendidikan Anak Usia Dini, 1(1), 19. https:// doi.org/10.31004/obsesi.v1i1.28

Artha, D. J. (2016). Pengaruh Pemilihan Tayangan Televisi Terhadap Perkembangan Sosialisasi Anak. EduTech, 2(1), 18-26.

Astarini, N., Hamid, S. I., \& Rustini, T. (2018). Studi Dampak Tavangan Televisi Terhadap Perkembangan Perilaku Sosial Anak. Cakrawala Dini: Jurnal Pendidikan Anak Usia Dini, 8(1). https://doi.org/10.17509/cd.v8i1.10554

Astuti, S., Putri, I., \& Ali, D. (2016). Strategi Komunikasi Program Internet Sehat Dan Aman Kementerian Komunikasi Dan Informatika Republik Indonesia (Studi Kasus Evaluasi Program Incakap Tahun 2015. Jurnal Komunikasi Untar.

Desti, S. (2005). Dampak Tayangan Film Di Televisi Terhadap Perilaku Anak. Dampak Tayangan Film Di Televisi Terhadap Perilaku Anak Jurnal Komunikologi, 2(1), 1-7.

Efendi, A., Astuti, P. I., \& Rahayu, N. T. (2017). Analisis Pengaruh Penggunaan Media Baru Terhadap Pola Interaksi Sosial Anak Di Kabupaten Sukoharjo. Jurnal Penelitian Humaniora, 18(2), 12. https://doi.org/10.23917/humaniora.v18i2.5188

Emzir. (2016). Metodologi Penelitian Kualitatif: Analisis data (V). PT. Rajagrafindo Persada.

Fadlurrohim, I., Husein, A., Yulia, L., Wibowo, H., \& Raharjo, S. T. (2020). Memahami Perkembangan Anak Generasi Alfa Di Era Industri 4.0. Focus : Jurnal Pekerjaan Sosial, 2(2), 178. https:/ / doi.org/10.24198/focus.v2i2.26235

Fansuri, H., Fansuri, H., Fansuri, H., Fansuri, H., Fansuri, H., Fakultas, D., Iain, U., \& Intan, R. (2011). Dosen Fakultas Ushuluddin IAIN Raden Intan Lampung. TAPIs, 7(.12), 1-30.

Hamzah, N. (2015a). Anarkisme dan Sensualisme Televisi Indonesia. Raheema, 2(1), 50-55. https:// doi.org/10.24260/raheema.v2i1.168

Hamzah, N. (2015b). Pengembangan Keterampilan Sosial Anak Usia Dini. IAIN Pontianak Press.

Khomaeny, E. F. F., Ulfah, M., \& Hamzah, N. (2020). Pengaruh Aktivitas Fisik Dan Lingkungan Alamiah Bagi Daya Tahan Tubuh Anak Usia Dini. Awlady: Jurnal Pendidikan Anak. https:// doi.org/10.24235/awlady.v6i2.6206

KPI. (2019). Program Hasil Riset Kualitas Program Siaran T V Periode I Tahun 2019.

Lesilolo, H. J. (2019). Penerapan Teori Belajar Sosial Albert Bandura Dalam Proses Belajar Mengajar Di Sekolah. Kenosis: Jurnal Kajian Teologi. https:// doi.org/10.37196/kenosis.v4i2.67

Maisari, S., \& Purnama, S. (2019). Peran Digital Parenting Terhadap Perkembangan Berpikir Logis Anak Usia 5-6 Tahun Di Ra Bunayya Giwangan. Awlady: Jurnal Pendidikan Anak. https:// doi.org/10.24235/awlady.v5i1.4012

McQuail, Dennis, W. S. (1985). Model-Model Komunikasi. Erlangga.

$\mathrm{Na}^{\prime} \square$ imah, K. (2009). Coparenting pada Keluarga Muslim [Co-parenting in Muslim Family]. Indigenous, Jurnal Ilmiah Berkala Psikologi, 11(1), 88-100.

Nazir, M. (2003). Metode Penelitian. Ghalia Indonesia.

Nurani Sujiono, Y. (2007). Konsep Dasar Pendidikan Anak Usia Dini. Universitas Negeri Jakarta. Nurhadi. (2006). Realitas dalam dunia Virtual. Jurnal Atma Nan Jaya Universitas Katolik Atma Jaya Jakarta Edisi, 1-6. 
Nurwita, S. (2019). Analisis Nilai-Nilai Agama dan Moral Anak Usia Dini dalam Tayangan Film Kartun Upin dan Ipin. Jurnal Obsesi : Jurnal Pendidikan Anak Usia Dini, 3(2), 506. https://doi.org/10.31004/obsesi.v3i2.252

Orange, T. \& L. O. (2005). The Media Diet for Kids. Jakarta: Serambi Ilmu Semesta. Serambi Ilmu Semesta.

Permana, R. S. M., Abdullah, A., \& Mahameruaji, J. N. (2019). Budaya Menonton Televisi di Indonesia: Dari Terrestrial Hingga Digital. ProTVF. https://doi.org/10.24198/ptvf.v3i1.21220

Radesky, J. S., \& Domoff, S. E. (2019). Mobile Media and Parenting. The International Encyclopedia of Media Literacy, 1-6. https:/ / doi.org/10.1002/9781118978238.ieml0167

Ramli, D. J. P. P. dan I. K. K. dan I. A. M. (2020). Dirjen PPI: Survei Penetrasi Pengguna Internet di Indonesia Bagian Penting dari Transformasi Digital. https://www.kominfo.go.id/content/detail/30653/dirjen-ppi-survei-penetrasipengguna-internet-di-indonesia-bagian-penting-dari-transformasidigital/0/berita_satker

Rubiyanto, R. (2018). Strategi Membidik Ketersediaan Audiens Dalam Industri Televisi (Studi Deskriptif Tayangan Film India ANTV). Bricolage: Jurnal Magister Ilmu Komunikasi, 4(01), 083. https:// doi.org/10.30813/ bricolage.v4i01.1654

Sayekti, O. M. (2019). Film Animasi “Nussa dan Rara Episode Baik Itu Mudah" sebagai Sarana Penanaman Karakter pada Anak Usia Dini. Jurnal Pendidikan Anak, 8(2), 164-171. https://doi.org/10.21831/jpa.v8i2.29093

Subur, S. (1970). Pendidikan Nilai: Telaah tentang Model Pembelajaran. INSANIA : Jurnal Pemikiran Alternatif Kependidikan, 3-16. https://doi.org/10.24090/insania.v12i1.215

Syukri, M., Sujoko, A., \& Safitri, R. (2019). Gerakan dan pendidikan literasi media kritis di indonesia (studi terhadap yayasan pengembangan media anak). MEDIAKOM. https://doi.org/10.32528/mdk.v2i2.1925

Thompson, J. B. (2015). Kritik Ideologi Global: Teori Sosial Kritis dan Kumunikasi Massa. IRCisoD.

Ulfah, M. (2019). Pendekatan Holistik Integratif Berbasis Penguatan Keluarga pada Pendidikan Anak Usia Dini Full Day. Jurnal Obsesi : Jurnal Pendidikan Anak Usia Dini. https:// doi.org/10.31004/obsesi.v4i1.255

Ulfah, M. (2020). Digital Parenting: Bagaimana Orang Tua Melindungi Anak dari Bahaya Digital? (N. Hamzah (ed.)). Edu Publisher.

Viandari, K. D., \& Susilawati, K. P. A. (2019). Peran pola asuh orangtua dan penggunaan gadget terhadap interaksi sosial anak prasekolah. Jurnal Psikologi Udayana. https://doi.org/10.24843/jpu.2019.v06.i01.p08 